Gut, 1972, 13, 544-550

\title{
Observations on folate absorption with particular reference to folate polyglutamate and possible inhibitors to its absorption
}

\author{
JANET PERRY AND I. CHANARIN \\ From the Clinical Research Centre and Northwick Park Hospital, Watford Road, Harrow, Middlesex
}

SUMmaRY A test system for detection of inhibitors to the enzyme which removes the glutamic acid peptide chain from folate polyglutamates (folate conjugase) is described. This utilizes the reaction between plasma conjugase and the folate polyglutamate in red blood cell haemolysate. Diphenylhydantoin and yeast extracts did not inhibit plasma conjugase.

The better absorption of monoglutamate forms of folate as compared to polyglutamate forms was confirmed. Polyglutamates were absorbed normally by patients with pernicious anaemia, suggesting that conjugase enzymes (optimally active at $p \mathrm{H} \mathrm{4.5)}$ ) did not normally function to a significant extent in the gut lumen. Diphenylhydantoin and bicarbonate did not interfere with absorption of either mono- or polyglutamate forms of folate.

Some 75 to $90 \%$ of folate in a mixed diet is in the form of a polyglutamate, that is, the pteroylglutamic acid moiety has a chain of generally six or more glutamic acid residues (Butterworth, Santini, and Frommeyer, 1963; Chanarin, Rothman, Perry, and Stratfull, 1968). During folate absorption the peptide chain is removed so that a monoglutamate reaches the blood (Streiff and Rosenberg, 1967; Perry and Chanarin, 1968; Hoffbrand and Necheles, 1968). The enzyme removing the glutamic acid residues (folate conjugase) has a $\mathrm{pH}$ optimum in man of 4.5 (Hoffbrand and Necheles, 1968; Rosenberg, Godwin, Streiff, and Castle, 1968) and is barely active at $p \mathrm{H}$ $5 \cdot 5$. Thus, although conjugase enzymes are present in the fluid in the gut lumen, probably derived from desquamated gut epithelial cells, it is debatable whether effective cleavage of the peptide chain from polyglutamates does occur in the gut lumen. It has also been suggested that natural inhibitors to the enzyme, folate conjugase, exist in foodstuffs such as yeast (Mims, Swendseid, and Bird, 1947) and these may prevent utilization of folate in the polyglutamate form (Hoffbrand, 1969). Interference with this enzyme (folate conjugase) has been postulated as one of the ways in which a number of drugs, including the anticonvulsant, diphenylhydantoin, and contraceptive pills may produce folate deficiency (Hoffbrand and Necheles, 1968; Rosenberg et al, 1968). Others Received for publication 10 May 1972. have claimed that diphenylhydantoin interfered with pteroylmonoglutamate absorption (Hepner, 1969) possibly by producing an alkaline $p \mathrm{H}$ in the gut lumen (Benn, Swan, Cooke, Blair, Matty, and Smith, 1971). Other compounds that have been reported to interfere with conjugases are cuprous chloride (Baugh, Krumdieck, Baker, and Butterworth, 1970), bromsulphthalein (Bernstein, Gutstein, Weiner, and Efron, 1970), and silver nitrate (Toennies and Phillips, 1959).

In view of the contradictory nature of recent reports in this field, folate absorption tests were carried out on a group of volunteers and tests were set up to detect inhibitors to the enzyme, folate conjugase. This paper describes our results.

\section{Materials and Method}

\section{ABSORPTION TESTS}

Tests were carried out on 12 healthy volunteers who were members of the laboratory staff and five patients with pernicious anaemia in remission. Fifteen mg of pteroylglutamic acid (PteGlu) was given orally 36 hours before each test. A blood sample was collected before administration of the oral test dose. The dose of folate given was $0.045 \mu \mathrm{M}$ per $\mathrm{kg}$ of body weight and blood samples were collected hourly for three or four hours. Urine was collected for six hours after the oral dose, $1 \mathrm{~g}$ of dry 
ascorbate being added to the urine bottle to prevent oxidation of reduced folate derivatives. The absorption of the following compounds was studied: pteroylglutamic acid (PteGlu), PteGlu + diphenylhydantoin $(100 \mathrm{mg})$, yeast polyglutamate $\left(\mathrm{PteGlu}_{x}\right)$, PteGlu $x+$ diphenylhydantoin $(100 \mathrm{mg})$, PteGlu $x$ after treatment with chick pancreatic conjugase, and PteGlu with $10 \mathrm{~g}$ bicarbonate.

The absorption of PteGlu with and without bicarbonate was tested on four volunteers, the other absorption tests with PteGlu and PteGlu $x$ on eight volunteers and the absorption of PteGlu and PteGlu $x$ alone was tested on five patients with pernicious anaemia in remission.

TESTS FOR FOLATE CONJUGASE INHIBITORS

Folate in human red blood cells is a polyglutamate and the folate in a haemolysate becomes available for microbiological assay only after reacting with a conjugase enzyme present in plasma. Like intestinal conjugase the optimum $p \mathrm{H}$ for plasma conjugase is $4 \cdot 5$. Blood was collected from a normal subject into heparin and red cells and plasma were separated. The red cells were washed three times in 10 volumes of saline and lysed in $1 \%$ ascorbate $p \mathrm{H} 4.5$ so that final concentration was 1 part red cells in 50 part diluent. In order to test for an inhibitor of folate conjugase the plasma (containing the conjugase enzyme) was incubated for 20 minutes at room temperature with the substance being tested and then haemolysate added. After a further 20 minutes' incubation the released folate was assayed microbiologically, or stored at $-20^{\circ} \mathrm{C}$ until assay. Appropriate controls were included as shown in Table I. Each tube was set up for assay in triplicate and the mixture assayed for released folate with Lactobacillus casei. If there was no inhibitory activity the folate activity of $A-B=C-D$ (Table I). If the inhibitor prevented release of folate from the haemolysate $A-B$ should be significantly less than $C-D$. In this system conjugase enzyme is present in excess. Appropriate dilution of plasma will result in an excess of substrate.

\begin{tabular}{|c|c|c|c|c|}
\hline $\begin{array}{l}\text { Volume } \\
(\mathrm{ml})\end{array}$ & A Test & B Blank & C Control & D Blank \\
\hline $\begin{array}{l}0.5 \\
0 \cdot 1 \\
0.5\end{array}$ & $\begin{array}{l}\text { Plasma } \\
\text { ? Inhibitor } \\
\text { Haemolysate }\end{array}$ & $\begin{array}{l}\text { Plasma } \\
\text { ? Inhibitor } \\
\text { Ascorbate } \\
\text { solution }^{1}\end{array}$ & $\begin{array}{l}\text { Plasma } \\
\text { Water } \\
\text { Haemolysate }\end{array}$ & $\begin{array}{l}\text { Plasma } \\
\text { Water } \\
\text { Ascorbate } \\
\text { solution }^{1}\end{array}$ \\
\hline
\end{tabular}

Table I Test for inhibitors of human plasma conjugase ${ }^{1} 1 \%$ ascorbate solution $p \mathrm{H} 4.5$

Guinea pig conjugase was prepared as described by Bernstein et al (1970) and inhibitors to this enzyme were looked for using both yeast polyglutamate and synthetic pteroylheptaglutamate as substrate.
PREPARATION OF TEST MATERIALS

Folate polyglutamate was concentrated from yeast powder (Difco) as previously described (Perry and Chanarin, 1968). Some of this material was incubated with chick pancreatic extract to remove the peptide chain. Results were checked by assaying an aliquot with L. casei and Streptococcus faecalis before use.

Pteroylglutamic acid was dried at $160^{\circ} \mathrm{C}$ and then used to prepare a solution of $2 \mathrm{mg}$ per $\mathrm{ml}$ in N/5 $\mathrm{NaOH}$.

Yeast concentrate was chromatographed on a DEAE cellulose (Whatman) column and fractions eluted by gradient elution (Schertel, Boehne, and Libby, 1965) to separate possible conjugase inhibitors from other folate-containing fractions (Hoffbrand, 1969). One hundred $\mathrm{ml}$ aliquots were collected and each was tested for possible inhibitor activity.

Diphenylhydantoin as an $0.01 \mathrm{M}$ solution was used. This compound had no effect on the results of microbiological assay procedures using $L$. casei and Str. faecalis.

Synthetic pteroylheptaglutamate, prepared by solid phase synthesis (Baugh and Krumdieck, 1968), was obtained through the courtesy of Dr E. L. R. Stokstad.

Microbiological assays were carried out with L.caseiand Str. faecalis as test organisms using Difco dehydrated media. Details are set out by Chanarin (1969). Unless otherwise stated all results are those obtained with $L$. casei assay and in absorption tests the folate content of the serum sample obtained before administration of the oral dose has been subtracted from the values in subsequent serum samples.

Chick pancreatic extract was prepared from freshly killed birds as described by Perry and Chanarin (1968).

\section{Results}

ABSORPTION OF PTEGLU AND PTEGLU $x$ With an oral dose of $0.045 \mu \mathrm{M} / \mathrm{kg}$ of PteGlu (20 $\mu \mathrm{g} / \mathrm{kg}$ ) healthy subjects showed a mean peak blood level of $52 \mathrm{ng} / \mathrm{ml}$ with a range of 25 to 106 $\mathrm{ng} / \mathrm{ml}$. With PteGlu $x$ the mean peak blood level was $12.9 \mathrm{ng}$ per $\mathrm{ml}$ with a range of 6 to $32 \mathrm{ng} / \mathrm{ml}$ (Fig. 1 and Table II).

The mean urinary excretion of folate after PteGlu was $302 \mu \mathrm{g}$ and after PteGlu $x 24 \mu \mathrm{g}$ (Fig. 2).

When Str. faecalis was used as the test organism the mean peak serum folate value after oral PteGlu was $35.9 \mathrm{ng} / \mathrm{ml}$ with a range of 8 to 62 . There was no detectable rise in serum folate level with Str. faecalis assay when PteGlu $x$ was given. The mean urinary folate excretion after PteGlu when measured with Str. faecalis was $200 \mu \mathrm{g}$. 


\begin{tabular}{|c|c|c|c|c|c|c|}
\hline \multirow[t]{2}{*}{ Oral Dose } & \multirow[t]{2}{*}{ Group No. } & \multicolumn{4}{|c|}{ Mean Peak Blood Level (ng/ml) } & \multirow{2}{*}{$\begin{array}{l}\text { Urine } \\
\text { ( } \mu \mathrm{g} / 6 \text { hours) }\end{array}$} \\
\hline & & $1 \mathrm{Hr}$ & $2 \mathrm{Hr}$ & $3 \mathrm{Hr}$ & $4 \mathrm{Hr}$ & \\
\hline
\end{tabular}

Table II Mean peak blood levels and urinary excretion after oral folate assayed with $L$. casei ${ }^{1}$

'Fasting serum folate values have been subtracted.

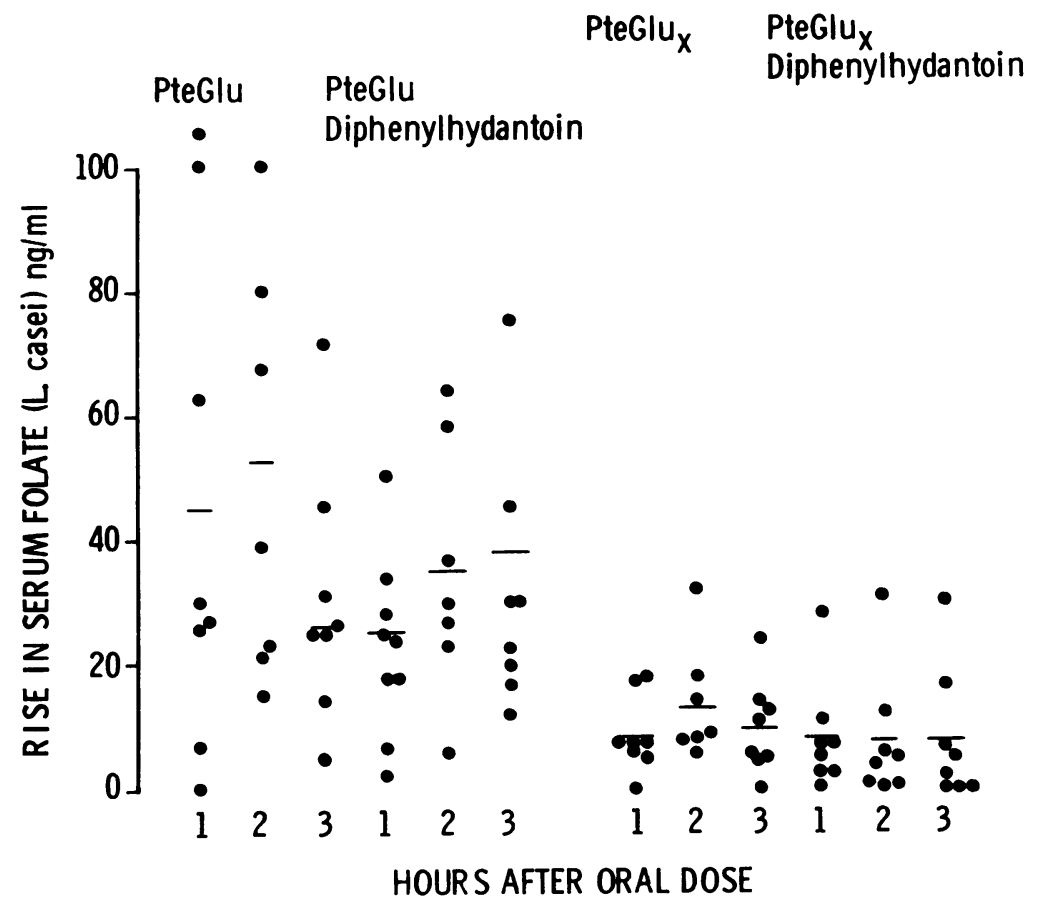

Fig. 1 The rise in serum folate after oral administration of $0.045 \mu \mathrm{m} / \mathrm{kg}$ of pteroylglutamic acid and yeast concentrate supplying pteroylpolyglutamate in healthy subjects. The effect of diphenylhydantoin on absorption was noted. The fasting serum folate level has been subtracted.

EFFECT OF PRETREATMENT OF PTEGLi $x$ WITH CONJUGASE ENZYME

To determine whether cleavage of the glutamic acid chain was the principal factor limiting absorption of PteGlu $_{x}$, the compound was incubated with chick pancreatic enzyme before being used in the absorption tests. There was a significantly greater rise in serum levels and urinary excretion of folate when compared with untreated PteGlu $x$. The mean peak serum folate level was $24.3 \mathrm{ng}$ per $\mathrm{ml}$ with a range of 16 to $68 \mathrm{ng}$ and the mean urinary excretion was $110 \mu \mathrm{g}$ (Fig. 2 and Table II).
EFFECT OF DIPHENYLHYDANTOIN ON FOLATE ABSORPTION

The dose of PteGlu and PteGlu $x$ was given to the same subjects with $100 \mathrm{mg}$ of diphenylhydantoin. After an oral dose of PteGlu given with diphenylhydantoin the mean peak serum folate level was $37.8 \mathrm{ng} / \mathrm{ml}$ with a range of 20 to $95 \mathrm{ng}$. The mean urinary excretion was $465 \mu \mathrm{g}$ (Fig. 3). These values were not significantly different from those obtained in the same subjects in the absence of diphenylhydantoin.

When PteGlu $x$ was given with diphenylhydantoin 


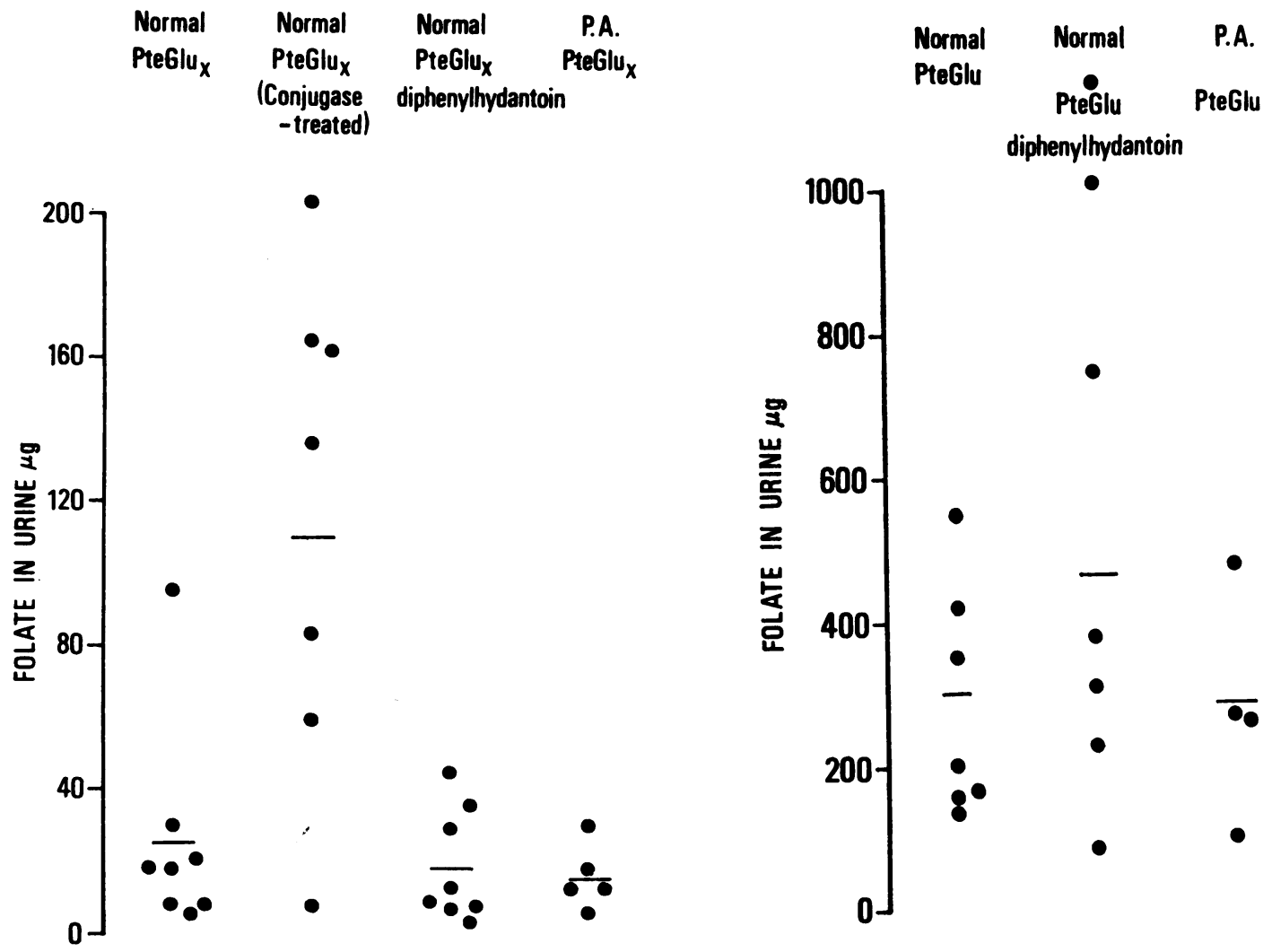

Fig. 2

Fig. 3

Fig. 2 The urinary excretion of folate after oral administration of yeast concentrate supplying pteroylpolyglutamate $(0.045 \mu \mathrm{m} / \mathrm{kg})$ in healthy persons and in subjects with pernicious anaemia in remission. The effect of pretreating the pteroylpolyglutamate with conjugase enzyme and of giving it with diphenylhydantoin is noted.

Fig. 3 Urinary excretion of folate after oral pteroylglutamic acid $(0.045 \mu \mathrm{m} / \mathrm{kg})$ in healthy persons with and without diphenylhydantoin and in subjects with pernicious anaemia in remission.

the mean peak serum folate level was $8 \cdot 2 \mathrm{ng} / \mathrm{ml}$ with a range of 3 to $30 \mathrm{ng} / \mathrm{ml}$ (Fig. 1). The mean urinary excretion was $17.7 \mu \mathrm{g}$ (Fig. 2). Again these values do not differ significantly from those obtained without diphenylhydantoin.

\section{EFFECT OF INTESTINAL $p$ H ON FOLATE} ABSORPTION

Following release of acidic gastric contents into the duodenum the $p \mathrm{H}$ in the upper region of the gut may fall to about 5.0 at least for a short time (Rhodes and Prestwich, 1966). Thus in normal subjects it might be possible for folate conjugase to have some activity at that $p \mathrm{H}$ and some cleavage of polyglutamate might take place in the jejunal lumen. On the other hand, in pernicious anaemia the gastric contents remain essentially neutral or even alkaline, and hence conjugase activity in the intestinal lumen is improbable. To obtain information about whether intestinal conjugase activity was likely to be of importance, the absorption of PteGlu and PteGlu $x$ was studied in five patients with pernicious anaemia (Figs. 2 and 3 and Table II). Following PteGlu the peak serum folate level ranged from 10 to $44 \mathrm{ng} / \mathrm{ml}$ (mean 28.2) and mean urinary excretion was $278 \mu \mathrm{g}$. Following PteGlu $_{x}$ the peak serum folate levels ranged from 6 to $30 \mathrm{ng} / \mathrm{ml}$ with a mean of $11 \cdot 8$. The mean urinary excretion in pernicious anaemia patients after PteGlu was $14.4 \mu \mathrm{g}$. The serum folate levels and urinary folate excretion after PteGlu $x$ in controls and in pernicious anaemia patients were not significantly different and it was concluded that conjugase activity in the intestinal lumen was not important in polyglutamate absorption. 
More recently Benn et al (1971) suggested that an alkaline intestinal $p \mathrm{H}$ was detrimental to the absorption of pteroylglutamic acid by the jejunum and that both diphenylhydantoin and bicarbonate acted by maintaining an alkaline $p \mathrm{H}$. Since this report was contrary to our experience with alkali, pteroylglutamic acid $(20 \mu \mathrm{g} / \mathrm{kg})$ was given to four subjects 36 hours after a $15 \mathrm{mg}$ oral dose of folate without, and 24 hours later with, $10 \mathrm{~g}$ bicarbonate. The mean serum folate levels one, two, and three hours after the oral dose given alone were 33, 20, and $15 \mathrm{ng} / \mathrm{ml}$ and when given with bicarbonate 102,67 , and $38 \mathrm{ng} / \mathrm{ml}$. When assayed with Str. faecalis as test organism the mean serum folate levels one, two, and three hours after the oral dose without bicarbonate were 20,12 , and $4 \mathrm{ng} / \mathrm{ml}$ and with bicarbonate were 59,64 , and $39 \mathrm{ng} / \mathrm{ml}$. These results were the opposite of those reported by Benn et al (1971), that is, the presence of alkali promoted pteroylglutamic acid absorption as judged by serum folate levels.

OBSERVATIONS ON CONJUGASE INHIBITORS

The following substances which have been claimed to have an inhibitory effect on the action of conjugase in splitting the glutamic acid residue from folate polyglutamate were studied: yeast extract, diphenylhydantoin, bromsulphthalein, silver nitrate, and cuprous chloride.

The only substance that consistently inhibited the action of conjugase enzymes without inhibiting the growth of the microbiological assay organisms was $\mathrm{Cu} \mathrm{Cl}{ }_{2}$. A typical study is shown in Table III. Cupric chloride had no effect on the growth of $L$. casei itself in aqueous solution or in plasma but incubation of plasma with $\mathrm{Cu} \mathrm{Cl}_{2}$ prevented release of folate from red cell folate polyglutamate.

\begin{tabular}{lllll}
\hline $\begin{array}{l}\mathrm{Cu} \mathrm{Cl} \\
(\mathrm{mg})\end{array}$ & $\begin{array}{l}\text { Plasma/Cu } \mathrm{Cl}_{2} / \text { Plasma/Cu } \\
\text { Haemolysate }\end{array}$ & $\begin{array}{l}\text { Plasmal } \\
\text { Haemolysate }\end{array}$ & Plasma \\
\hline 10 & $15^{1}$ & 8 & 110 & 8 \\
1 & 13 & 8 & 110 & 8 \\
1 & 81 & 6 & 110 & 7 \\
\hline
\end{tabular}

Table III Effect of $\mathrm{Cu} \mathrm{Cl}_{2}$ in inhibiting human plasma conjugase

${ }^{1} L$. case $i$ activity (ng/ml)
We have been unable to show that diphenylhydantoin, bromsulphthalein (BSP), silver nitrate or yeast extracts had any inhibitory activity on human plasma conjugase. The results were not influenced by varying concentrations of the 'inhibitor' or of these substances. Bromsulphthalein at the concentration used by Bernstein et al (1970) inhibited the growth of $L$. case $i$ in aqueous solution (Table IV). Thus some of the results reported by these workers may be due

\begin{tabular}{lll}
\hline $\begin{array}{l}\text { BSP/Tube } \\
(\mu \mathrm{g})\end{array}$ & \multicolumn{2}{l}{ Pteroylglutamic Acid $(\mathrm{ng})$} \\
\cline { 2 - 3 } & Added & Recovered \\
\hline 2000 & $1 \cdot 0$ & 0 \\
1500 & 1.0 & 0 \\
1000 & $1 \cdot 0$ & 0 \\
500 & $1 \cdot 0$ & Trace \\
200 & 1.0 & $0 \cdot 2$ \\
0 & 1.0 & 1.0 \\
\hline
\end{tabular}

Table IV Effect of bromsulphthalein on growth of L. casei in the presence of pteroylglutamic acid

to inhibition of the assay organism. Satisfactory growth of $L$. casei, however, was obtained in the presence of BSP when plasma was present in the system.

Although BSP had no effect on human plasma conjugase, an inhibitory effect was observed on guinea pig conjugase using synthetic pteroylheptaglutamate as substrate as described by Bernstein et al (1970) at a concentration of heptaglutamate of $1000 \mathrm{ng} / \mathrm{ml}$. The results shown in Table $\mathrm{V}$ are representative of a large number of experiments with many different combinations of reactants.

\section{Discussion}

Our results confirm that a concentrate of folate polyglutamate derived from natural sources is not as well absorbed by man as a solution of pteroylglutamic acid. These results are not in agreement with those obtained in man using relatively pure synthetic heptaglutamate (Butterworth, Baugh, and Krumdieck, 1969; Rosenberg and Godwin, 1971). The former group found that 37 and $67 \%$ of labelled polyglutamate was retained and the latter that

\begin{tabular}{|c|c|c|c|c|c|}
\hline System & $\begin{array}{l}\text { PteGlux }+ \\
\text { Conjugase } \\
\text { (ng) }\end{array}$ & $\begin{array}{l}\text { PteGlux }+ \\
\text { Conjugase }+ \text { BSP } \\
\text { (ng) }\end{array}$ & $\begin{array}{l}\text { PteGlu } \\
\text { BSP } \\
\text { (ng) }\end{array}$ & $\begin{array}{l}\text { Conjugase Alone } \\
\text { (ng) }\end{array}$ & $\begin{array}{l}\text { PteGlux Alone } \\
\text { (ng) }\end{array}$ \\
\hline $\begin{array}{l}\text { Human plasma RBC haemolysate } \\
\text { BSP } 1000 \mu \mathrm{g}\end{array}$ & $108^{1}$ & 108 & 5 & 5 & - \\
\hline $\begin{array}{l}\text { Synthetic PteGlu, GP conjugase } \\
\text { BSP } 1000 \mu \mathrm{g}\end{array}$ & 1000 & 270 & 130 & 15 & 100 \\
\hline
\end{tabular}

Table V Effect of bromsulphthalein on human and guinea pig conjugase

${ }^{2} L$. case $i$ assay of monoglutamate form of folate. 
synthetic folate heptaglutamate was as well absorbed as pteroylglutamic acid. There are various possible explanations for these major discrepancies.

It has been suggested that yeast, which is the starting material for concentration of folate polyglutamate, contains inhibitors which prevent the conjugase enzyme splitting off the glutamic acid chain. Removal of the peptide chain is an essential step in absorption of folate polyglutamate. The major study on conjugase inhibitors was carried out by Mims, Swendseid, and Bird in 1947. They incubated the preparation which was being tested for inhibitor activity with substrate and source of conjugase for 18 hours at $37^{\circ} \mathrm{C}$. The Str. faecalis activity released was assayed microbiologically. A decreasing yield of folate activity with increasing amounts of 'inhibitor' substance was taken as evidence of an inhibitor. However, such a result could be obtained if conjugase activity released reduced unstable folate derivatives. In the absence of reducing conditions such compounds are likely to be oxidized and cleaved at the 9-10 position. The 'inhibitors' in vitro were in fact not active in vivo.

As we have failed to find any dietary or pharmacological substances other than $\mathrm{Cu} \mathrm{Cl}_{2}$ which were potent inhibitors of human conjugase enzyme we are uncertain of the value or sensitivity of the system proposed for their detection. Nevertheless, we have been unable to demonstrate that the yeast preparations we used had any inhibitory activity for the folate conjugase enzyme and the view that poor absorption of natural folate polyglutamate is due to inhibitors is unproven.

Synthetic folate polyglutamate prepared by the solid phase method is an unnatural substrate insofar as the material entering blood is active for Str. faecalis. Natural substrates are all reduced folate derivatives and with these only 5,methyltetrahydrofolate appears in blood. This form is only active microbiologically with $L$. casei. This too, may in part explain the difference in absorption of natural and synthetic polyglutamate.

Another possibility to be considered is that the faecal excretion results reported are too low. Details of the measurement of small mounts of ${ }^{14} \mathrm{C}$ in faeces were not reported. This would not apply, however, to results based on urinary excretion methods. Thus, the explanation for the reported discrepancies in absorption of natural and synthetic polyglutamate is not clear and further data are required to resolve the problem.

Using isolated intestinal segments in the dog, however, Baugh, Krumdieck, Baker, and Butterworth (1971) found that the longer the glutamic acid chain length the poorer the intestinal absorption as judged by folate blood levels.
Our data confirm the study reported by Jandl and Lear (1956) that the ability to remove the peptide chain is a limiting factor in folate polyglutamate absorption. Thus there is considerable improvement in absorption when the folate polyglutamate was pretreated with conjugase. The absorption was still not as good as with an equimolar amount of pteroylglutamic acid, possibly because the conjugase did not break the polyglutamate down completely to monoglutamate. In vivo transfer of folate polyglutamate into the intestinal cell may represent the chief limitation to folate polyglutamate absorption rather than inadequacy of conjugase activity.

Normal folate polyglutamate absorption in pernicious anaemia patients (Hoffbrand, 1971) suggests that cleavage of the peptide chain does not occur significantly in the gut lumen although the enzyme, whether derived from intestinal or pancreatic secretion or from desquamated intestinal cells, is available. The $p \mathrm{H}$ in the gut rarely falls low enough to permit conjugase activity, and in pernicious anaemia in particular, is unlikely to fall much below neutrality. Thus, it is probable that removal of the peptide chain is intracellular and lysosomes have been suggested as a likely site for this reaction within the cell since not only do enzymes with low $p \mathrm{H}$ optima act in this site but folate conjugase is present in lysosomes in relatively high amount (Hoffbrand and Peters, 1969).

Other substances such as contraceptive tablets (McLean, Heine, Held, and Streiff, 1969; Strieff, 1970) and diphenylhydantoin have been proposed as inhibitors of the conjugase enzyme since some of these substances may be associated with the development of a megaloblastic anaemia due to folate deficiency. In common with others we have failed to confirm that diphenylhydantoin had any effect on folate absorption in vivo or on conjugase activity in vitro (Baugh and Krumdieck, 1969). The action of diphenylhydantoin on folate metabolism remains unknown.

We have also failed to confirm that diphenylhydantoin had any adverse effect on folate absorption by virtue of producing an alkaline $p \mathrm{H}$ in the gut lumen. When folate absorption was carried out with the addition of bicarbonate there was an augmentation of folate absorption. For this reason we have always carried out folate absorption with the dose dissolved in N/5 NaOH (Chanarin and Bennett, 1962). Higher blood folate levels in patients with achlorhydria after oral folate were noted by Clark (1953). We are at a loss to explain the results obtained by Benn et al (1971) who reported impairment of pteroylglutamic acid absorption when given with bicarbonate. 


\section{References}

Baugh, C. M., and Krumdieck, C. L. (1968). The solid phase synthesis of polyglutamates of folic acid. (Abstr.) Fed. Proc., 27, 455.

Baugh, C. M., and Krumdieck, C. L. (1969). Effects of phenytoin on folic acid conjugases in man. Lancet, 2, 519-521.

Baugh, C. M., Krumdieck, C. L., Baker, H. J., and Butterworth, C. E., Jr. (1970). The intestinal absorption of polyglutamates of folic acid. Fed. Proc., 29, 634. (Abstr.)

Baugh, C. M., Krumdieck, C. L., Baker, H. J., and Butterworth, C. E., Jr. (1971). Studies on the absorption and metabolism of folic acid. I. Folate absorption in the dog after exposure of isolated intestinal segments to synthetic pteroylpolyglutamates of various lengths. J. clin. Invest., 50, 2009-2021.

Benn, A., Swan, C. H. J., Cooke, W. T., Blair, J. A., Matty, A. J., and Smith, M. E. (1971). Effect of intraluminal $p \mathrm{H}$ on the $\mathrm{ab}-$ sorption of pteroylmonoglutamic acid. Brit. med. J., 1, 148-150.

Bernstein, L. H., Gutstein, S., Weiner, S., and Efron, G. (1970). The absorption and malabsorption of folic acid and its polyglutamates. Amer. J. Med., 48, 570-579.

Butterworth, C. E., Jr., Baugh, C. M., and Krumdieck, C. L. (1969). A study of folate absorption and metabolism in man utilizing carbon-14 labeled polyglutamates synthesized by the solid phase method. J. clin. Invest., 48, 1131-1142.

Butterworth, C. E. Jr., Santini, R., Jr., and Frommeyer, W. B., Jr. (1963). The pteroylglutamate components of American diets as determined by chromatographic fractionation. J. clin. Invest., 42, 1929-1939.

Chanarin, I. (1969). The Megaloblastic Anaemias. Blackwell, Oxford.

Chanarin, I., and Bennett, M. C. (1962). Absorption of folic acid and D-xylose as tests of small intestinal function. Brit. med.J., 1 985-989.

Chanarin, I., Rothman, D., Perry, J., and Stratfull, D. (1968). Normal dietary folate, iron, and protein intake, with particular reference to pregnancy. Brit. med. J., 2, 394-397.

Clark, S. L., Jr. (1953). Oral folic acid tolerance test in normal human subjects and patients with pernicious anemia. Proc. Soc. exp. Biol. (N.Y.), 82, 25-28.
Hepner, G. W. (1969). The absorption of pteroylglutamic (folic) acid in rats. Brit. J. Haemat., 16, 241-249.

Hoff brand, A. V. (1969). Polyglutamyl forms of folate acid in man. (Letter). Brit. med. J., 1, 51.

Hoff brand, A. V. (1971). Folate absorption. J. clin. Path., Suppl. 24 (Roy. Coll. Path.), 5, 66-76.

Hoff brand, A. V., and Necheles, T. F. (1968). Mechanism of folate deficiency in patients receiving phenytoin. Lancet, 2, 528-530.

Hoff brand, A. V., and Peters, T. J. (1969). The subcellular localization of pteroyl polyglutamate hydrolase and folate in guinea pig intestinal mucosa. Biochim. biophys. Acta (Amst.), 192, 479-485.

Jandl, J. H., and Lear, A. A. (1956). The metabolism of folic acid in cirrhosis. Ann. intern. Med., 45, 1027-1044.

McLean, F. W., Heine, M. W., Held, B., and Streiff, R. R. (1969) Relationship between the oral contraceptive and folic acid metabolism. Amer. J. Obstet. Gynec., 104, 745-747.

Mims, V., Swendseid, M. E., and Bird, O. D. (1947). The inhibition of pteroylglutamic acid conjugase and its reversal. The effect of nucleic acid- and sulphydryl-combining reagents.J. biol.Chem., 170, 367-377.

Perry, J., and Chanarin, I. (1968). Absorption and utilization of polyglutamyl forms of folate in man. Brit. med.J., 4, 546-549.

Rhodes, J., and Prestwich, C. J. (1966). Acidity at different sites in the proximal duodenum of normal subjects and patients with duodenal ulcer. Gut, 7, 509-514.

Rosenberg, I. H., and Godwin, H. A. (1971). The digestion and absorption of dietary folate. Gastroenterology, 60, 445-463.

Rosenberg, I. H., Godwin, H. A., Streiff, R. R., and Castle, W. B (1968). Impairment of intestinal deconjugation of dietary folate. Lancet, 2, 530-532.

Schertel, M. E., Boehne, J. W., and Libby D. A. (1965). Folid acid derivatives in yeast. J. biol. Chem., 240, 3154-3158.

Streiff, R. R. (1970). Folate deficiency and oral contraceptives.J. Amer. med. Ass., 214, 105-108.

Streiff, R. R., and Rosenberg, I. H. (1967). Absorption of polyglutamic folic acid. (Abstr.) J. clin. Invest., 46, 1121.

Toennies, G., and Phillips, P. M. (1959). Blood folic acid studies. I. Resolution of precursor and enzyme fractions of the blood folic acid system. J. biol. Chem., 234, 2369-2372. 